\title{
PENGARUH BID ASK SPREAD, VARIANS RETURN, VOLUME PERDAGANGAN, DAN HARGA SAHAM TERHADAP HOLDING PERIOD SAHAM
}

\section{THE EFFECT OF BID ASK SPREAD, RETURN VARIANS, TRADE VOLUME, AND STOCK PRICE ON SHARE PERIOD}

\author{
Ida Subaida ${ }^{1)}$, Rini Kartika Sari ${ }^{2}$ \\ ${ }^{1}$ Idaa.subaida@gmail.com \\ ${ }^{2}$ rinikartika1903@gmail.com \\ ${ }^{1,2}$ Universitas Abdurachman Saleh Situbondo
}

\begin{abstract}
ABSTRAK
Pasar modal atau pasar saham merupakan wadah untuk mempertemukan penjual dan pembeli instrument keuangan dengan tujuan investasi. Keberadaan pasar modal memberikan peran terhadap berbagai pihak seperti perusahaan, investor, dan bahkan untuk perekonomian nasional. Informasi yang benar atas sahamsaham perusahaan dalam pasar saham dibutuhkan investor sebagai keputusan jual beli saham dan juga untuk keputusan menahan atau melepas kepemilikan aset keuangan. Tujuan penelitian ini adalah untuk menganalisis dan memberikan bukti empirik tentang pengaruh bid ask spread, varians return, volume perdagangan, dan harga saham terhadap holding period saham pada perusahaan terdaftar di Bursa Efek Indonesia Indonesia yang termasuk kategori perusahaan LQ45. Sampel penelitian adalah sebanyak 45 sampel yang berupa perusahaan terdaftar di Bursa Efek Indonesia Indonesia yang termasuk kategori perusahaan LQ45 tahun 2017. Pengujian hipotesis dilakukan dengan regresi linier berganda menggunakan SPSS versi 22. Hasil penelitian adalah bid ask spread, varians return, volume perdagangan, dan harga saham tidak berpengaruh terhadap holding period saham
\end{abstract}

Kata Kunci: bid ask spread, varians return, volume perdagangan, harga saham, dan holding period saham.

\section{ABSTRACT}

The capital market or stock market is a place to bring together sellers and buyers of financial instruments with investment objectives. The existence of the capital market provides a role for various parties such as companies, investors, and even for the national economy. The correct information about the company's shares in the stock market is needed by investors as a decision to buy and sell shares and also for the decision to hold or release ownership of financial assets. The purpose of this study is to analyze and provide empirical evidence about the effect of bid ask spread, return variance, trading volume, and stock price on the holding period of shares in companies listed on the Indonesia Indonesia Stock Exchange 
which are categorized as LQ45 companies. The research sample was 45 samples in the form of companies listed on the Indonesia Indonesia Stock Exchange which included the LQ45 company category in 2017. Hypothesis testing was done using multiple linier regresion analysis using SPSS version 22. The results of the study were bid ask spread, variance return, trading volume, and stock price that does not affect the holding period

Keywords: bid ask spread, varians return, trading volume, stock price, dan holding period.

\section{PENDAHULUAN}

Pasar modal atau pasar saham merupakan wadah untuk mempertemukan penjual dan pembeli instrument keuangan dengan tujuan investasi. Keberadaan pasar modal memberikan peran terhadap berbagai pihak seperti perusahaan, investor, dan bahkan untuk perekonomian nasional. Pasar modal memberikan ruang dan peluang bagi perusahaan untuk memperoleh sumber pendanaan yang relatif lebih rendah dibandingkan dengan pasar uang. Peran pasar modal juga dapat dirasakan oleh investor yaitu untuk memperoleh return atas aset keuangan yang dimilikinya yang diperoleh melalui perdagangan di pasar modal. Sedangkan bagi perekonomian nasional, pasar modal memiliki peran penting dalam rangka mendorong dan meningkatkan pertumbuhan dan stabilitas ekonomi. Peran bagi perekonomian nasional diperoleh dengan cara ketersediaan dana bagi perusahaan yang akan meningkatkan produktifitas perusahaan dan return yang akan meningkatkan keuntungan dari dana yang dimiliki investor (Hadi, 2013).

Informasi yang benar atas saham-saham perusahaan dalam pasar saham dibutuhkan investor sebagai keputusan jual beli saham dan juga untuk keputusan menahan atau melepas kepemilikan aset keuangan. Pihak yang memiliki informasi lebih berkaitan dengan kondisi perusahaan dalam ini adalah pihak manajemen perusahaan, penting untuk menyampaikan informasi kepada pasar saham terutama investor. Jika informasi tersebut merupakan sinyal baik bagi investor, maka investor akan bereaksi positif terhadap saham perusahaan yang bersangkutan (Maulina, 2012). 
Salah satu bentuk reaksi investor berkaitan dengan saham yang diperdagangkan di pasar modal adalah yang biasa disebut dengan holding period. Holding period adalah jangka waktu yang dibutuhkan investor untuk menahan dananya pada saham tertentu untuk waktu tertentu (Maulina, 2012).

Investor memiliki kebebasan untuk memilih saham perusahaan yang diperdagangkan di pasar saham. Investor juga memiliki kebebasan dalam menentukan jumlah lembar saham dan lamanya memegang saham tersebut. Dalam melakukan hal tersebut investor harus memiliki pertimbangan untuk mengurangi risiko sampai tingkat tertentu dan untuk mendapatkan gain yang maksimal. Jika investor beranggapan bahwa saham yang dimilikinya tersebut menguntungkan, maka hal yang perlu dilakukan adalah menahan saham tersebut dalam waktu yang lebih lama dengan harapan harga jual saham tersebut akan meningkat di waktu yang akan datang. Sebaliknya jika investor menganggap bahwa saham yang dimilikinya akan mengalami penurunan dimasa mendatang, maka yang perlu dilakukan adalah melepas saham tersebut untuk mengurangi risiko yang akan dihadapinya (Yulianto, 2008). Oleh karena itu lama tidaknya seorang investor menahan dananya pada suatu saham perusahaan tertentu menarik untuk diteliti.

Maulina (2012) melakukan penelitian yang berjudul informasi asimetri dan periode menahan kepemilikan saham LQ45 di bursa efek Indonesia. Penelitian tersebut memperoleh hasil bahwa varians return dan bid ask spread tidak berpengaruh terhadap holding period.

Penelitian yang dilakukan oleh Yulianto (2008) yang berjudul analisis pengaruh bid ask spread, market value, dan risiko saham terhadap holding period (studi kasus pada saham-saham LQ45 periode 2003-2005) memperoleh hasil hasil yang berbeda dengan hasil penelitian yang dilakukan (Malulina, 2012). Hasil penelitian tersebut adalah bid ask spread berpengaruh positif terhadap holding period dan risiko saham berpengaruh negatif terhadap holding period saham. Ratnasari (2014) juga melakukan penelitian tentang holding period saham dan 
memperoleh hasil yang juga bebeda dengan penelitian Maulina (2012) dan Yulianto (2008) yaitu bid ask spread berpengaruh negatif terhadap holding period. Hasil kedua dari penelitian tersebut sama dengan hasil penelitian Maulina (2012) yaitu varians return tidak berpengaruh signifikan terhadap holding period.

Penelitian yang dilakukan oleh Maulina (2010) memperoleh hasil bahwa bid ask spread berpengaruh positif terhadap holding period saham. Hasil tersebut sama dengan hasil penelitian Yulianto (2008). Hasil selanjutnya yaitu market value berpengaruh positif terhadap holding period dan varians return berpengaruh negatif terhadap holding period. Hasil varians return tersebut bertentangan dengan hasil penelitian yang dilakukan oleh Maulina (2012) dan Ratnasari (2014).

Berdasarkan pentingnya holding period saham untuk diamati lebih lanjut yang telah dipaparkan diatas dan karena terdapat perbedaan hasil penelitianpenelitian sebelumnya, maka peneliti tertarik untuk meneliti penelitian yang berjudul pengaruh bid ask spread, varians return, volume perdagangan, dan harga saham terhadap holding period saham. Penelitian ini merupakan pengembangan dari penelitian-penelitian yang telah ada sebelumnya dengan menggabungkan variabel-varaibel atau faktor-faktor yang mempengaruhi holding period saham yang telah diteliti pada beberapa penelitian terdahulu.

\section{METODE PENELITIAN}

Populasi dalam penelitian ini adalah perusahaan terdaftar di Bursa Efek Indonesia Indonesia yang termasuk kategori perusahaan LQ45 tahun 2017. Sampel penelitian ditentukan menggunakan purposive sampling, yaitu suatu metode pemilihan sampel yang memiliki tujuan atau target tertentu. Pemilihan sampel ditentukan dengan kriteria (a) Menyediakan informasi yang dibutuhkan dalam penelitian ini selama tahun 2017 (b) Tidak pernah dihentikan perdagangannya dari Bursa Efek Indonesia selama periode pengamatan 


\section{Variabel Penelitian}

Variabel independen dalam penelitian ini sebanyak empat variabel. Variabel tersebut yaitu bid ask spread, varians return, volume perdagangan saham, dan harga saham.

\section{1) Bid ask spread}

Bid ask spread merupakan persentase selisih antara bid price atau harga beli dan ask price atau harga jual (Maulina, 2012). Bid ask spread dalam penelitian ini dihitung dengan rumus (Purwanto, 2007 dalam Nurul (2009):

$$
\text { Spread }=\frac{A s k-B i d}{A s k} \times 100
$$

\section{2) Varians return}

Varians return adalah tingkat risiko yang terjadi dari suatu kegiatan investasi sebagai akibat dari totalitas harga saham (Maulina, 2012). Varians return dalam penelitian ini dihitung menggunakan rumus berikut (Dwi, 2008):

$$
R_{t}=\frac{\left(P_{t}-P_{t-1}\right) \times 100 \%}{P_{t-1}}
$$

Dimana:

$\mathrm{R}_{\mathrm{t}} \quad$ : Return Saham periode $\mathrm{t}$

$\mathrm{P}_{\mathrm{t}} \quad$ : Harga Penutupan Saham periode $\mathrm{t}$

$\mathrm{P}_{\mathrm{t}-1} \quad$ : Harga Penutupan Saham periode $\mathrm{t}-1$

3) Volume perdagangan

Volume perdagangan saham merupakan jumlah lembar saham yang diperdagangkan pada waktu tertentu untuk setiap jenis saham yang diteliti. Volume perdagangan saham pada penelitian ini diukur dengan volume perdagangan saham.

4) Harga saham

Harga pasar saham adalah harga yang terbentuk di pasar saham. Harga pasar saham berbeda dengan nilai buku saham. Semakin sedikit informasi yang diperoleh untuk menghitung harga saham, maka perbedaan harga pasar dan nilai 
buku menjadi semakin jauh. Semakin sedikit informasi yang terdapat dalam pasar saham, maka harga saham semakin dipengaruhi oleh tekanan psikologis pembeli maupun penjual (Halim, 2015).

Variabel independen dalam penelitian ini adalah holding period. Holding Period merupakan variabel yang memberikan indikasi tentang rata-rata panjangnya waktu investor untuk menahan saham suatu perusahaan. Holding period dalam penelitian ini dihitung dengan rumus Atkin dan Edward (1990) dalam Maulina (2012):

$$
\mathbf{H P}_{\text {it }}=\frac{\text { rata-rata jumlah saham } \mathrm{i} \text { yang beredar pada tahun ket }}{\text { rata-rata volume perdagangan saham } \mathrm{i} \text { pada tahun ket }}
$$

Metode Analisis Data

Metode analisis yang digunakan adalah analisis regresi linear bergnda dengan menggunakan SPSS versi 22. Menurut Hasan (2010) regresi linear berganda adalah regresi linear dimana sebuah variabel terikat (variabel Y) dihubungkan dengan dua atau lebih variabel bebas (variabel X). Secara umum bentuk persamaan garis regresinya adalah:

Keterangan:

$$
\mathrm{Y}=\mathrm{a}+\mathrm{b}_{1} \mathrm{X}_{1}+\mathrm{b}_{2} \mathrm{X}_{2}+\mathrm{b}_{3} \mathrm{X}_{3}+\mathrm{b}_{4} \mathrm{X}_{4}
$$

$\begin{array}{ll}\mathrm{Y} & =\text { Holding period } \\ \mathrm{X}_{1} & =\text { Bid ask spread } \\ \mathrm{X}_{2} & =\text { Varians return } \\ \mathrm{X}_{3} & =\text { Volume perdagangan } \\ \mathrm{X}_{4} & =\text { Harga saham } \\ \mathrm{a} & =\text { intercept } \text { atau konstanta } \\ \mathrm{b}_{1}, \mathrm{~b}_{2}, \mathrm{~b}_{3}, \mathrm{~b}_{4}=\text { koefisien regresi }\end{array}$

\section{HASIL PENELITIAN DAN PEMBAHASAN}

Sampel akhir yang digunakan dalam penelitian ini adalah sebanyak 45 sampel. Pengujian hipotesis dalam penelitian ini menggunakan analisis regresi linear berganda. Analisis regresi digunakan untuk mengetahui pengaruh Bid Ask Spread, Varians Return, Volume Perdagangan, dan Harga Saham terhadap Holding Period Saham. Hasil pengujian hipotesis dapat dilihat pada tabel 1. 
Tabel 1. hasil pengujian hipotesis

\begin{tabular}{|c|c|c|c|c|c|}
\hline \multirow[t]{2}{*}{ Model } & \multicolumn{2}{|c|}{$\begin{array}{c}\text { Unstandardized } \\
\text { Coefficients }\end{array}$} & \multirow{2}{*}{$\begin{array}{c}\text { Standardized } \\
\text { Coefficients } \\
\text { Beta }\end{array}$} & \multirow[t]{2}{*}{$t$} & \multirow[t]{2}{*}{ Sig. } \\
\hline & $B$ & $\begin{array}{l}\text { Std. } \\
\text { Error }\end{array}$ & & & \\
\hline$($ Constant $)$ & 1292,057 & 244,978 & & 5,274 &, 000 \\
\hline Bid Ask Spread & $-.057,928$ & 129,410 &,- 066 & -.448 & ,657 \\
\hline Varians Return & $-10,589$ & 165,165 &,- 009 &,- 064 & ,949 \\
\hline Volume & $-6220 \mathrm{E}-6$ &, 000 &,- 283 & - & ,069 \\
\hline Perdagangan & & & & , 1872 & \\
\hline Harga Saham &, 015 & ,010 & ,226 & 1,513 & , 138 \\
\hline
\end{tabular}

a. Dependent Variable: Nilai perusahaan

Sumber: data diolah dari output SPSS

Hipotesis 1 menyatakan bahwa Bid Ask Spread berpegaruh positif terhadap Holding Period Saham. Hasil pengujian statistik menunjukkan bahwa tingkat signifikansi 0,657. Tingkat signifikansi tersebut lebih besar dari 5\% atau 0,05 , sehingga hipotesis 1 tidak didukung. Hasil penelitian menunjukkan bahwa Bid Ask Spread tidak berpengaruh terhadap Holding Period Saham. Hasil penelitian ini konsisten dengan penelitian Luh dan Bagus (2016) dan penelitian yang dilakukan Winda dan Abundanti (2015) yaitu Bid Ask Spread tidak berpengaruh terhadap Holding Period Saham. Hasil penelitian ini tidak konsisten dengan penelitian Selvia dan Fauzie (2013) dan Rahayu dan Asandimitra (2017).

Luh dan Bagus (2016) melakukan penelitian tentang pengaruh spread, market value,variance return dan deviden payout ratio terhadap holding period saham. Penelitian terebut dilakukan pada perusahaan sektor industri dasar kimia periode 2011-2014. Pemilihan sektor industri dasar kimia sebagai sampel penelitian karena sektor tersebut merupakan salah satu sektor dari perusahaan 
manfaktur yang memiliki kapitalisasi yang besar yang dapat menyebabkan fenomena holding period dapat dengan mudah dijelaskan. Hasil penelitian yaitu spread tidak berpengaruh terhadap holding period saham dijelaskan oleh Luh dan Bagus (2016) sebagai akibat dari terdapat beberapa perusahaan yang menjadi sampel penelitian memiliki kinerja saham yang baik yang membuat investor berusaha memperoleh return yang maksimal dari spread saham..

Hasil penelitian ini juga konsisten dengan penelitian Winda dan Abundanti (2015). Hasil tersebut disebabkan oleh perusahaan yang menjadi sampel penelitian merupakan perusahaan besar dan sahamnya aktif diperdagangkan. Hal tersebut dapat mengakibatkan pergerakan saham yang tinggi tidak menyebabkan investor menahan sahamnya lebih lama.

Dalam penelitian ini perusahaan yang dipilih menjadi sampel adalah perusahaan yang termasuk kategori LQ-45 yang merupakan 45 perusahaan terdaftar di Bursa Efek Indonesia terbaik menurut kategori LQ-45. 45 perusahaan tersebut pasti memiliki kinerja saham yang baik sehingga investor mungkin menginginkan capital gain dari saham yang memiliki spread yang tingi. Investor-investor perusahaan tersebut juga dapat memutuskan menahan atau melepas sahamnya tidak hanya dari tingginya bid ask spread.

Hipotesis 2 menyatakan bahwa Varians Return berpengaruh positif terhadap Holding Period Saham. Hasil pengujian statistik menunjukkan tingkat signifikansi 0,949. Hal tersebut menjelaskan bahwa hipotesis 2 tidak didukung. Varians Return tidak berpengaruh terhadap Holding Period Saham.

Hasil penelitian konsisten dengan penelitian yang dilakukan oleh Rahayu dan Asandimitra (2017) dan Luh dan Bagus (2016) yang melaporkan bahwa Varians Return tidak berpengaruh terhadap Holding Period Saham. Hasil penelitian ini tidak konsisten dengan penelitian yang dilakukan Selvia dan Fauzie (2013) dan Selvia dan Fauzie (2013), yang melaporkan bahwa Varians Return berpengaruh terhadap Holding Period Saham. 
Rahayu dan Asandimitra (2017) melakukan penelitian mengenai Varians Return dan Holding Period Saham pada perusahaan sektor pertambangan yang terdaftar di Bursa Efek Indonesia. Perusahaan yang menjai sampel penelitian adalah berbagai sektor yang terdapat di Bursa Efek Indonesia. Hasil penelitian menunjukkan bahwa Varians Return tidak berpengaruh terhadap Holding Period Saham. Hasil tersebut dikarenakan sampel yang digunakan terlalu rendah dan homogen yang disebabkan oleh penelitian Rahayu dan Asandimitra (2017) menggunakan asumsi rata-rata varians saham.

Penelitian Luh dan Bagus (2016) melakukan penelitian mengenai Varians Return dan Holding Period Saham yang dilakukan pada perusahaan sektor industri dasar kimia. Hasil penelitian menolak hipotesis yang dirumuskan yaitu Varians Return berpengaruh terhadap Holding Period Saham. Hasil tersebut disebabkan karena perilaku investor adalah untuk memperoleh capital gain atas selisih harga jual dan harga beli saham. Saham yang memiliki nilai yang tinggi juga akan menyebabkan saham tersebut memiliki resiko yang tinggi. Saham dengan resiko tinggi tersebut akan tetap dibeli oleh investor.

Hasil penelitian ini konsisten dengan penelitian sebelumnya yang telah dijelaskan tersebut. Varians Return bukan merupakan satu-satunya yang menjadi pertimbangan investor dalam memutuskan untuk menahan atau melepas kepemilikan sahamnya. Seperti yang dijelaskan oleh penelitian sebelumnya meskipun resiko saham tinggi, investor akan tetap membeli suatu saham dengan pertimbangan-pertimbangan lain misalnya memberikan capital gain yang tinggi.

Hipotesis 3 menyatakan bahwa Volume Perdagangan Saham berpegaruh positif terhadap Holding Period Saham. Hasil pengujian statistik menunjukkan bahwa tingkat signifikansi 0,069. Tingkat signifikansi tersebut lebih besar dari $5 \%$ atau 0,05, sehingga hipotesis 3 tidak didukung. Hasil penelitian menunjukkan bahwa Volume Perdagangan Saham tidak berpengaruh terhadap Holding Period Saham. Perusahaan yang perdagangan sahamnya aktif yang dicerminkan dengan volume perdagangan saham yang tinggi bukan merupakan hal yang 
mempengaruhi keputusan investor untuk melepas atau menahan saham yang dimilikinya.

Hipotesis 4 menyatakan bahwa Harga Saham berpengaruh positif terhadap Holding Period Saham. Hasil pengujian statistik menunjukkan tingkat signifikansi 0,138. Hal tersebut menjelaskan bahwa hipotesis 4 tidak didukung. Harga Saham tidak berpengaruh terhadap Holding Period Saham. Hasil penelitian konsisten dengan penelitian yang dilakukan oleh Amnesti (2018) dan Aditya dan Margasari (2018). Amnesti (2018) melakukan penelitian mengenai Harga Saham dan Holding Period Saham yang dilakukan pada perusahaan manufaktur yang terdaftar di Bursa Efek Indonesia. Hasil Penelitian yaitu Harga Saham tidak berpengaruh terhadap Holding Period Saham. Hal tersebut menurut Amnesti (2018) disebabkan karena sebaran data yang terlalu beragam pada sampel penelitian yang dipilih.

Hasil penelitian juga didukung oleh hasil penelitian yang dilakukan oleh Aditya dan Margasari (2018). Penelitian tesebut meneliti Harga Saham dan Holding Period Saham pada perusahaan yang tercatat dalam indeks LQ 45. Hasil penelitian yaitu Harga Saham tidak berpengaruh terhadap Holding Period Saham.

\section{SIMPULAN DAN SARAN}

Hasil penelitian menunjukkan bahwa Bid Ask Spread tidak berpengraruh terhadap Holding Period Saham. Pergerakan saham yang tinggi tidak menyebabkan investor menahan sahamnya lebih lama. Varians Return juga terbukti tidak berpengaruh terhadap Holding Period Saham. Varians Return bukan merupakan satu-satunya yang menjadi pertimbangan investor dalam memutuskan untuk menahan atau melepas kepemilikan sahamnya. Resiko saham yang tinggi tetap membuat investor membeli suatu saham dengan pertimbanganpertimbangan lain misalnya memberikan capital gain yang tinggi. Volume Perdagangan Saham dan Harga Saham juga terbukti tidak berpengaruh terhadap Holding Period Saham. 
Hasil penelitian ini mempunyai implikasi yaitu dapat menjadi bahan masukan dalam pengambilan keputusan investasi, khususnya keputusan untuk menahan atau melepas kepemilikan saham oleh investor. Penelitian ini juga memiliki implikasi kebijakan yaitu memberikan masukan terhadap kebijakan mengenai harga dan volume saham yang dimiliki oleh perusahaan.

Berdasarkan hasil penelitian dan kesimpulan penelitian ini, peneliti ingin memberikan saran kepada peneliti berikutnya agar menambah variabel independen atau faktor-faktor lain lain yang diduga dapat berpengaruh terhadap Holding Period Saham. Penelitian selanjutnya dapat meneliti dalam periode pengamatan yang lebih baru yaitu 2018 dan seterusnya. Perusahaan pada periode pengamatan yang lebih baru mungkin dapat lebih memungkikan bagi investor untuk menangkap sinyal-sinyal terkait saham yang dapat mempengaruhi keputusan menahan atau melepas kepemilikan sahammnya.

\section{DAFTAR PUSTAKA}

Aditya, Nurwahid W dan Margasari, Naning. 2018. Analisis Faktor yang Mempengaruhi Holding Period Saham pada Perusahaan Go Public yang Tercatat di Indeks LQ-45. Jurnal Fakultas Ekonomi:635-646.

Amnesti, Thalia S. 2018. Determinan Stock Holding Period (Studi Pada Perusahaan Manufaktur di Bursa Efek Indonesia Periode 2013-2016). Jurnal Manajemen Bisnis Indonesia, Edisi 4:438-448.

Dwi, Sri A A. 2008. Pengaruh Return Saham, Volume Perdagangan Saham dan Varian Return Saham Terhadap Bid-Ask Spread Saham pada Perusahaan Manufaktur yang Tergabung dalam Indeks LQ 45 Periode Tahun 20032005.

Hadi, Nor. 2013. Pasar Modal: acuan teoritis dan praktis investasi di instrumen keuangan pasar modal. Graha Ilmu: Yogyakarta.

Halim, Abdul. 2015. Analisis investasi dan aplikasinya. Jilid 1. Salemba Empat: Jakarta.

Hasan, Iqbal. 2010. Analisis data Penelitian dengan Statistik. Jakarta: PT. Bumi Aksara.

Luh,Ni Ayu Y.U dan Bagus, Ida P.S. 2016. Pengaruh Spread, Market Value,Variance Return Dan Deviden Payout Ratio Terhadap Holding Period Saham. Matrik: Jurnal Manajemen, Strategi Bisnis, dan Kewirausahaan, Vol. 10, No.2:168-178. 
Maulina, Vinus. 2010. Analisis faktor yang mempengaruhi holding period saham biasa pada perusahaan go public yang tercatat dalam index LQ45. WACANA. Vol. 13, No. 3:398-416.

Maulina, Vinus. 2012. Informasi asimetri dan periode menahan kepemilikan saham LQ 45 di Bursa Efek Indonesia. Disertasi Universitas Brawijaya.

Nurul, Lulu. I. 2009. Pengaruh harga saham, trading volume activity, dan risiko saham terhadap bid ask spread (studi pada perusahaan LQ45 di Bursa Efek Indonesia). MODERNISASI. Vol. 5, No 3-199-210).

Rahayu, Titik N dan Asandimitra, Nadia. 2017. Pengaruh Bid Ask Spread,Market Value, dan Variance Return terhadap Holding Period Saham Sektor Pertambangan yang Listing di Bursa Efek Indonesia (BEI) Tahun 20112015. Junal Ilmu Manajemen Vol. 5, No.3-1-10.

Ratnasari, Desi dan Astuti, Dewi. 2014. Pengaruh bid ask spread, market value, dan varians return terhadap holding period. FINESTA. Vol. 2. No 1:99102.

Selvia, Novita M.P dan Fauzie, Syarif. 2013. Jurnal Ekonomi dan Keuangan, Vol. 1, No. 3:154-167.

Winda, Ely S dan Abundanti, Nyoman. 2015. Determinan Penentu Holding Period pada Indeks LQ-45. E-jurnal Manajemen Unud, Vol.4, No.12:429-458.

Yulianto, Helmi. H. 2008. Analisis pengaruh bid ask spread, market value, dan resiko saham terhadap holding period (studi kasus pada saham-saham LQ45 periode 2003-2005). 